\section{ESCENA}

Revista de las artes
Publicación semestral. ISSN 2215-4906

Volumen 78 - Número 2

Enero - Junio 2019

\title{
Martín de la Cruz López Moya, Caleidoscopio sonoro. Músicas urbanas en Chiapas
}

Anna María Fernández Poncela

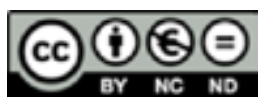

Esta obra está bajo una licencia Creative Commons Reconocimiento-No comercial-Sin Obra Derivada 
Reseñas

\title{
Martín de la Cruz López Moya, Caleidoscopio sonoro. Músicas urbanas en Chiapas
}

\author{
Anna María Fernández Poncela ${ }^{1}$ \\ Universidad Autónoma Metropolitana \\ Ciudad de México, México
}

\begin{abstract}
Recibido: 6 de mayo de 2018 Aprobado: 8 de agosto del 2018
\end{abstract}
Dicen que el tiempo no existe o es eterno y que el espacio, en caso de que sí exista, es infinito. El tiempo musical de un espacio se aterriza en el territorio, lugar, experiencia, sentimiento; lo arraiga y siembra, brota, crece, florece, fructifica y se convierte en paisaje sonoro. Ese espacio preñado de imágenes, olores y tactos musicales se multiplica y expande, es el encuentro de los tiempos. Específicamente, la música chiapaneca tiene espacios y tiempos locales e internacionales. Desde hace décadas atravesó los cuatro continentes con el bolero y el chachachá y ahora lo vuelve a hacer con el etnorock, pasado y presente se entretejen y proyectan hacia el futuro. A Chiapas, y, en concreto, a San Cristóbal de las Casas, llegan músicos de todo el mundo a compartir sus melodías, a dialogar con los locales, a aprender y a enseñar, a compartir saberes y experiencias tal como relata Martín de la Cruz López Moya, en su obra, en este trasiego internacional de la contemporaneidad. Los músicos locales, por su parte parecen inspirarse en la música del mundo, la adaptan y recrean, vierten su vivencia, sus costumbres, sus creencias y su lengua, la resignifican, la producen y consumen, se la apropian como identidad toda vez que la devuelven a la globalidad. Para focalizar este asunto hay que enmarcarlo como se hace en la parte introductoria de Caleidoscopio sonoro:

En ese contexto de visibilización de Chiapas en una escena política y mediática globalizada, las prácticas creativas o artísticas se posicionaron como las actividades más dinámicas del espectáculo en la esfera pública local y, al mismo tiempo, como foco de atención de las iniciativas oficiales de promoción cultural. La convergencia de sujetos políticos emergentes en el contexto neozapatista, muchos de ellos portadores de saberes artísticos, propició un enriquecimiento de las creatividades culturales en el espacio local. La escena musical de esta entidad, además, se diversificó y enriqueció al experimentar nuevas corrientes: ensambles, fusiones o mezclas entre tradiciones sonoras. En San Cristóbal de

1 Profesora e investigadora de la Universidad Autónoma Metropolitana, México. Doctora Antropología Cultural Universidad de Barcelona, España. Correo electrónico: fpam1721@correo.xoc.uam.mx 
las Casas, por ejemplo, la diversificación de la música en vivo va de la mano con las transformaciones en los usos del espacio público, así como la intensificación de la experiencia colectiva de la nocturnidad (López Moya, 2017, p. 20).

Asimismo, el autor de este libro nos lleva de la mano amablemente a un recorrido musical del Estado de Chiapas en el suroeste de México. Pretende "dibujar un paisaje sonoro diverso, rico y ágil en Chiapas" (López Moya, 2017, p. 22) y, añadimos aquí, lo consigue. Caleidoscopio que metafóricamente señala como "cada imagen musical es producto de la confluencia de diversos fractales" (López Moya, 2017, p. 167). Tiempos y espacios, contextos sociales y políticos, trasiegos musicales nativos o extranjeros.

Parte de algunas aproximaciones teóricas y conceptuales de la etnomusicología y de los estudios culturales, para ir caminando por la música popular como experiencia y sentir cotidiano, toda vez que creación de identidad cultural. Prosigue con las geografías musicales, el baile como expresión corporal, la danza ceremonial y el baile folklórico. Se adentra en la marimba, instrumento musical Fuente: López Moya (2017). por excelencia de la región que Imagen 1. Portada del libro

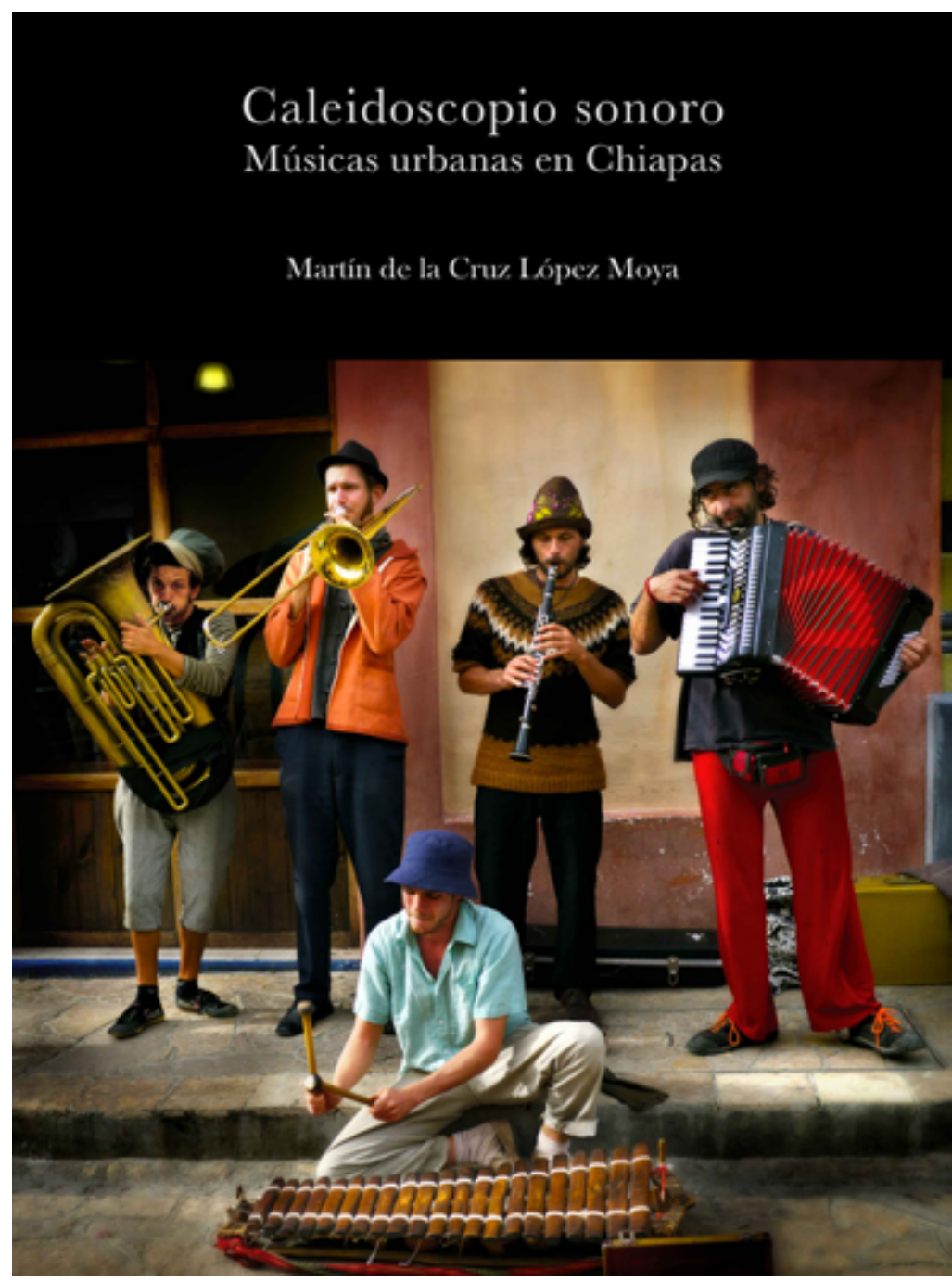
además se dice cuna de la misma, su historia y su desarrollo, música alegre y nostálgica de otros tiempos, del porvenir y de la actualidad, la más popular y la más cotidiana, la más escuchada y la más amada. 
Martín de la Cruz López Moya,

Sigue a través de las memorias musicales con autores locales de renombre internacional, los hermanos Domínguez, parte indiscutible de la educación sentimental de Chiapas, de México y me atrevería a decir que del mundo, pues en conciertos en directo, como parte de la discografía, o enlatada en películas, surcó mares y cielos y, para mucha gente en cierta época -décadas de 1930 y 1940- fue referencia musical clave y, aún hoy, lo es. En especial, se aborda la historia de dos canciones y sus múltiples versiones que atraviesan los espacios y los tiempos: "Perfidia" y "Frenesí".

Así, llega a la época reciente -década de 1990- y, en concreto, a nuestros días, donde tiene lugar el entramado entre música local tradicional e indígena y el rock, y surge el etnorock -también llamado rock indígena- de carácter y raigambre autóctono y con efluvios internacionales. De nuevo Chiapas y, quizás, México por extensión -pues este género está presente también en otros Estados de la República- se catapulta geográficamente desde el gusto local musical hasta la internacionalización del mismo como en otra época aconteciera. Aquí entra el intercambio entre músicos de diferentes procedencias y países, estilos e intereses, pero que, al final, comparten saberes musicales, ideas y sentimientos. Aquí la identidad indígena, la lengua, los gustos y tradiciones reverberan a través de ritmos importados inicialmente, pero emocionalmente vividos y sentidos como propios. Además, hay que sumar las políticas culturales que se desarrollan al respecto, desde proyectos concretos hasta conciertos y festivales varios.

Hacemos un inciso en cuanto a la presentación del capitulado del libro que se retomará con posterioridad. Estas manifestaciones culturales merecen especial atención, pues por cuestiones socioeconómicas y por razones étnico culturales, la región con altos niveles de pobreza, de conflictividad política y de marginación indígena, parece expresarse en la música cuando

comenzaron a aparecer manifestaciones antes no practicadas en el espacio local que proponen la defensa de las lenguas originarias: el bats í rock (rock verdadero, en tsotsil) o Yok'el Jkumaltick (el sonido de nuestra palabra, en tojolabal), como el "etnorock", el "etnoblues", o la fusión de armonías del jazz con sonoridades locales que da como resultado el jazz latino o experimentos que pueden denominarse como jazz "chiapaneco" y "etnojazz". Estas iniciativas de intercambio musical favorecen el diálogo y la diversidad social (López Moya, 2017, p. 169).

Al respecto, se podría pensar que, en un Estado con tantas problemáticas de pobreza y marginación, de conflictividad social y política, y de profunda y amplia discriminación, el estudiar la música pudiera considerarse algo superfluo o poco serio. No obstante, la música es parte de la vida, es expresión cultural y emocional, nos acompaña desde la cuna a la sepultura. Y por eso son bienvenidas investigaciones y estudios que también nos muestren el lado bello del mundo, de las relaciones sociales y de la existencia misma. Cuando 
músicos locales y de otras latitudes intercambian experiencias y saberes, suman esfuerzos, borran fronteras de todo tipo -no solo las geográficas- y se hermanan, ahora sí y sin metáfora: en una sola voz. Son un ejemplo a observar, divulgar, incluso me atrevería a decir que a seguir y, por supuesto, no solo para el ámbito musical.

Prosiguiendo con otro apartado de la obra, ya hacia la finalización de la misma, llegamos al florecimiento de intercambio internacional que también aparece en el jazz, con la llegada como se dijo de músicos de diferentes tipos y con el asentamiento de gustos musicales en el lugar. Por lo que el jazz bebe también del paisaje musical local y renace con nuevos bríos y seguidores. El etnorock y el jazz son en nuestros días parte del paisaje cotidiano musical del Estado de Chiapas y "dialogan con la globalidad" (López Moya, 2017, p. 169), sin olvidar la eterna e infinita marimba y otros estilos, como deja claro Martín de la Cruz López Moya en su obra.

El autor señala, hacia el final del texto, cómo la región ha sido objeto de múltiples influencias y confluencias culturales, y hoy acontece lo propio también, pues "la sonoridad urbana de Chiapas exalta diversas formas de chiapanequidad: mestizas, indígenas y globales, portadoras de distintas narrativas que arrastran tras de sí historicidades y experiencias sociales diversas. Por ello, el paisaje sonoro local es complejo, rico, creativo" (López Moya, 2017, p. 167). En el bordado sonoro, la tradición y la innovación se entretejen y complementan como se afirma en el capítulo final de este libro:

La marimba, el etnorock y el jazz en Chiapas son resultado de la convergencia de saberes, de la multiplicidad de gustos musicales y de hibridaciones que se corresponden con un entramado histórico, social y cultural diverso que está siendo jaloneado por flujos globales, el consumo musical en la era digital y la estrategia narrativa de la tradición (López Moya, 2017, p. 179).

El libro se cierra con el dossier "Presagio de los confines: la pasión musical en Chiapas", un despliegue de magníficas fotografías de Efraín Ascencio Cedillo, que visualiza algunas de las escenas de bailes e interpretaciones musicales descritas en la obra. Si trillado parece el dicho "una imagen vale más que mil palabras", aquí podríamos adaptarnos a lo que nos ocupa "una imagen vale más que mil melodías", pero más que diferenciar y separar, y como el ejemplo de los músicos descritos en este libro nos enseña: sumemos imágenes, palabras, bailes, sonidos y corazones, en este encuentro de los tiempos, espacios y músicas con la vida.

\section{Referencia}

López Moya, M. (2017). Caleidoscopio sonoro. Músicas urbanas en Chiapas (incluye Dossier fotográfico: "Presagio de los confines: la pasión musical en Chiapas" de Efraín Ascencio Cedillo). Chiapas: UNICACH/UNAM/JP. 